\title{
Erratum to: Dynamics of cell and tissue genesis in the male reproductive system of ticks (Acari: Ixodidae) Amblyomma cajennense (Fabricius, 1787) and Amblyomma aureolatum (Pallas, 1772): a comparative analysis
}

Bruno Rodrigues Sampieri • Marcelo Bahia Labruna •

Odair Correa Bueno • Maria Izabel Camargo-Mathias

Published online: 14 March 2014

(C) Springer-Verlag Berlin Heidelberg 2014

Erratum to: Parasitol Res

DOI 10.1007/s00436-014-3795-y

The original version of this article inadvertently contained a mistake. In the article title, the species name "Amblyomma cajennense" lacks the last "n". Also, in Figure 1, some labels on the image were incorrect. The correct article title and Figure 1 are shown here.

The online version of the original article can be found at http://dx.doi.org/ 10.1007/s00436-014-3795-y.

B. R. Sampieri • O. C. Bueno • M. I. Camargo-Mathias $(\bowtie)$

UNESP, Rio Claro, SP, Brazil

e-mail: micm@rc.unesp.br

M. B. Labruna

USP, São Paulo, SP, Brazil 


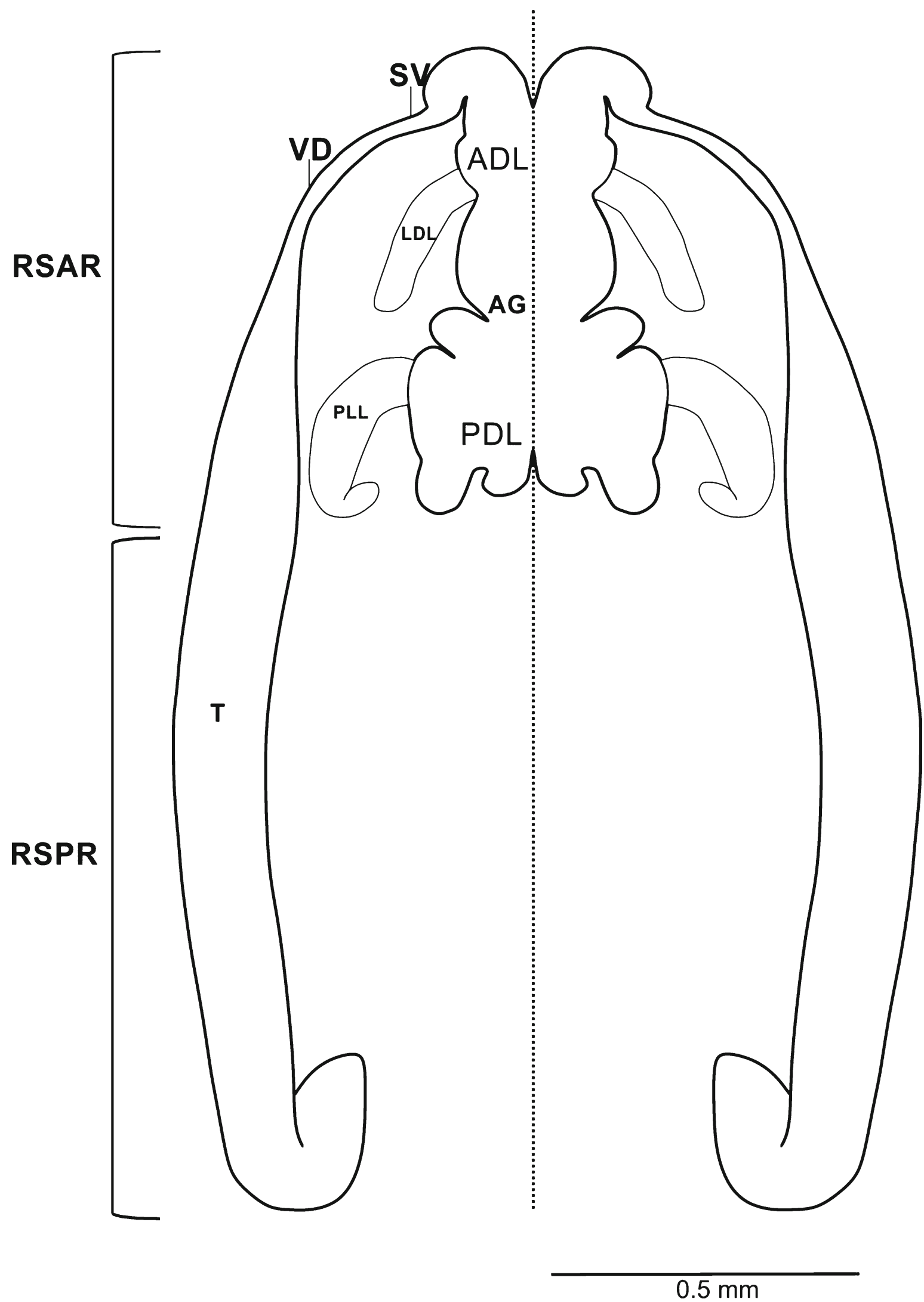

Fig. 1 Schematic representation of the male reproductive system of $A$. aureolatum and $A$. cajennense, showing: RSAR reproductive system anterior region, $A G$ accessory gland complex, $A D L$ antero-dorsal lobe,
$L D L$ latero-dorsal lobe, $P D L$ postero-dorsal lobe, $P L L$ postero-lateral lobe, $S V$ seminal vesicle, $V D$ vasa deferentia, $R S P R$ reproductive system posterior region, $T$ testis 